\title{
Political ethics about the phenomenon of politics in its interaction with morality
}

\author{
Marina Shirokova ${ }^{1, *}$ \\ ${ }^{1}$ Altai State University, 656049, 61a Lenina ave., Barnaul, Russia.
}

\begin{abstract}
The article considers the reasons for the formation of political ethics as a science and a discipline. Its appearance was caused by the crisis of the state domestic and foreign policies in the 1960s and 1970s, the collapse of value orientations in the public consciousness, as well as the loss of the authority of politics in the eyes of society. All this led to a steadily high interest in ethical issues and criticism of politics from a moral standpoint. The author traces the evolution of the interpretation of the concept of politics from antiquity to our days. Like all human activities, politics needs values and the axiological system. But in the modern world, the dehumanization of politics is taking place. Thus, the issue of restoring ties between politics and morality is largely a matter of continuing existence and prospects for human development.
\end{abstract}

\section{Introduction}

Political ethics was introduced as a discipline some time ago into the structure of higher education in Political Science. Its appearance is due to the processes of differentiation of modern political science, as well as the pressing demands of life. The concept of political ethics as an area of political knowledge was first developed in Germany at the beginning of the 20th century by representatives of sociological and anthropological approaches to politics. In the works of M. Weber, it is said about the "ethics of conviction" and the "ethics of responsibility"; M. Scheler proposes the concepts of "ethics of persuasion" and "ethics of success". A few decades ago, the term "political ethics" became scientific, and a corresponding university discipline appeared.

\section{The essence of interaction existing between politics and morality}

As E. L. Dubko writes, political ethics, or moral and political philosophy (in the old transcription), is a relatively young science, bordering on the philosophy of morality, the philosophy of history, philosophy and history of politics, sociology, the theory of state and law, social psychology, and other disciplines. It raises important polemical questions on which the fate of society as a whole and the life of people depend [1]. The history of its

* Corresponding author: mshirokova1 @ rambler.ru 
isolation from other sciences, as already mentioned, dates back to the beginning of the twentieth century. But political ethics became of independent importance in the Western developed countries in the 1960s-1970s.

Political ethics is the answer to the cultural shock, the disintegration of value orientations, to the profound crisis of the internal and foreign policies of states in the 1960s. At that time, state policies rapidly lost credibility in the eyes of society and were criticized and obstructed right up to civil disobedience, primarily from the left and youth movements. Another ideological polarization was emerging in Western societies. Quite unexpectedly, the revolutionary consciousness, once again, became stronger and took on distinct forms. Everyone was talking about the crisis, crises were everywhere: the crisis of controllability, the crisis of the national state, the crisis of confidence, the crisis of democracy, the crisis of political parties, the crisis of ideology, the crisis of the economy, the crisis of politics, the moral crisis, etc.

It is at this time that there was a consistently high interest in ethical issues, a pronounced ethical concern and, perhaps, a "renaissance" of ethics. In the 1970s, when there was a new wave of political philosophy, two controversial and undoubtedly significant works devoted equally to morality and politics appeared, R. Nozick's books “Anarchy, State. and Utopia” (1974) and J. Rawls's "Theory of Justice” (1971).

Prominent representatives of Catholic and Protestant theology, church figures (R. Niebuhr, P. Tillich, K. Wojtyla, B. Sutor, and others) addressed the problems of political ethics. For almost two decades, the church was leading in the humanistic movement and for its part supported the social demands of the working people. In part, this was due to the desire to win the sympathy of those sections of the population who were little interested in religion for some time (intellectuals, workers). In order not to lose its importance in society and not to be in the history archive, the church had to formulate its position on a number of pressing social problems and, of course, on policy issues [1].

In connection with the proclaimed "renaissance of ethics", as a science, as an academic discipline, and as a normative basis of politics, there is an increasing interest in the very concept of politics among researchers, which of its interpretations most closely approximate politics and morality and which separate them from each other.

In antiquity, ethical rationalism dominated, according to which knowledge itself was good, and ignorance itself was evil. With respect to politics, this means that only people with knowledge can govern. Only a wise man can eliminate anarchy and order all individual and social affairs of people, harmonize their relations, just as the gods once ordered the chaos and created the cosmos, that is, the world structured in a certain way. This is the ultimate goal of politics. Outside politics, a person is either God or a beast, but no longer a person, since a person is a political being. And the policy is the best part of the cosmos.

In the Middle Ages, the connection between ethics and rationality, which was characteristic of antiquity, and between virtue and knowledge weakened and was generally torn in some cases. Man thought himself, first of all, as a religious being, who was dual by nature, located between the world of animals and the world of angels. Hence, various forms of dualism became actual: churches and the state, the city of God and the hail of the earth, as well as spirit and flesh. Politics was perceived as a kind of a link between them, as an activity aimed at creating a Christian state and facilitating the path to the salvation of all its inhabitants.

In the Modern Times, if we talk primarily about the Western civilization, which actively transmits its values to the rest of the world, there was a gradual secularization and rationalization of politics, and the economic and commercial spirit began to penetrate more and more. People lived more in economic reality than in political reality. However, the Newest Time, brought with it the catastrophe of world wars, revolutions, global problems, 
unprecedented transformations of political systems, made the people realize themselves again in political reality. It was not accidental that political science appeared as an independent science. But over the past several centuries of modernization, rationalization, and commercialization, Political Science has largely distanced itself from ethics, and political activity - from morality. Thus, the second half of the 20th and the beginning of the 21 st century was marked by the "renaissance of ethics," the increased attention to the ethical aspects of politics, and the creation of concepts of political ethics that can be viewed as attempts to restore at least the appearance of a link between morality and politics. Consequently, politics discredited itself in eyes of society. Mankind has realized the very real threats that political actors being involved in politics as a game would lead the world to the third world war. More than that, they would not be able and want to prevent this from happening. And the stakes in the game are higher than ever in history.

H. Ortega y Gasset wrote after the Second World War that social life was a conceptual life, but our understanding of this life leaved much to be desired. "Today everyone talks all the time ... about good and bad politics, about peace and militancy, about the homeland and about humanity, about social justice and injustice, about social justice and injustice, about collectivism and capitalism ... about authoritarianism, about the individual and collectivity, etc. ", but "all the ideas that are being talked about, for which they are struggling and about which they argue, are strikingly confused and extremely vague," and therefore "one of the significant misfortunes of our time has been a sharp disparity between meaning, which today acquired all these issues, and rudeness and confusion in terms of their expression ..." [2]. To form an idea of politics, the philosopher explains, "conceptual series" are necessary. There is a close connection between political ideas and truths. "Politics is the most effective and visible side of public life, but it is secondary and is caused by hidden and insensible causes. And political inertia would not be so painful, if it did not stem from a deeper and more significant intellectual and moral stagnation. Therefore, without analyzing the latter, the question under investigation will not be clarified" [3]. In general, politics is a teleological phenomenon. The job of politics is to create conditions and prerequisites for the realization of certain goals. Politics accelerates the movement of society toward these goals. And to achieve this or that goal, it is necessary, first of all, to organize politically. But if there is no goal, then politics becomes meaningless and illegitimate, that is, it loses moral justification from the point of view of society.

E.L. Dubko, in his Political Ethics, distinguishes between politics and morality, a kind of their topography, which, from the beginning of the modern era, looks approximately as follows. Politics occupies a public sphere, and the private sphere is a territory of morality. "When the private sphere expands, the public sector decreases; when the public sector expands, the area of morality is curtailed. Morality and politics are fighting for territory. Everything looks as if private being struggles with social being in order to get and defend the space for development" [1]. And if moral imperatives cease to influence political activity, at least to formulate political goals, then it seems that politics hinders morality and, consequently, simple human happiness, that politics has nothing to do with human relations and feelings, does not take into account either subjectivity, nor the sense that it is something second-rate and unauthentic.

The classical field of belief is morality and religion. Then science becomes such a field. Politics is also a field of belief, but people can easily act in it without conviction. Politically, it does not matter whether the necessary steps are motivated by beliefs, or they are to be made under the influence of something else.

Like all human activities, politics needs values, an axiological system, which, however, constantly depreciates in one way or another. The policy contains relative truths. Politics is all about making deals with conscience, compromises in which is the essence of the matter dissolves, the situation in which is the mind; this is seemingly motor of progress, frankly 
decomposing the moral consciousness and forcing it to compromise. Hence, the following conclusion comes: "politics is a dirty business." This is the established tradition. Politics is the object of the worst suspicions, which are more than justified due t0 being based on experience.

It seems that politics is a field of action. At the same time, it is a masked and conspiratorial activity. One can never know for sure what is happening in it. Often we are dealing with a hypocritical and deceitful policy.

Politics positions itself as something serious, even comparing itself with "business." But in reality, politicians often fall into the category of social parasites. Politics bears the stamp of parasitic life, although it wants to seem more important than the so-called "politics for politicians" [1].

It is natural that the denial of politics is the dominant approach in public opinion. Dubko writes that politics has turned into a strange object, evoking general contempt, disappointment, ridicule and resentment. "People do not know what to expect and demand from politics, they do not know what to think about it. Usually, they find it difficult to determine its value, its essential meaning, and often feel like hiding from politics, keeping it at a safe distance from significant areas of life, giving it to others, and not spending their own lives on it. Politics seems to them an ambivalent thing: on the one hand, being alien and dangerous (the world of villains), and being fair and comic (the world of clowns), on the other hand" [1].

It is appropriate to quote also academician of the Russian Academy of Sciences A.A. Huseynov, the author of a large number of scientific works and textbooks on ethics. Of course, he evaluates politics from the ethical point of view, although for political scientists it is possible and more preferable to have a reverse view, which is the evaluation of ethics from the standpoint of politics as one of the tools in the political struggle. But it is the philosophical and ethical approach, which is very impartial in relation to politics, that makes it possible to clarify some of its aspects, which are invisible "from within." Huseynov notes, "The most immoral in contemporary Russian politics, I believe, is that it lacks politics. There is a struggle for power, intrigues, adventures, administration, firefighting, lobbying - anything. There is no policy as an all-Russian affair as joint efforts for a better life, as the arena of heroism and service to the common good. It's a social jungle, not politics." The researcher continues, "The degradation of politics is not an individual feature of our country ... Something similar is happening in other countries ... Politics has lost its initial isolation for the common good, which is the basis of its moral legitimacy. With the examples of morality in politics today, things are bad" [4]. Let's pay attention that the struggle for power, as it is said here, is not politics. Politics is a service to the common good.

The words of the philosopher N. A. Berdyaev are well-known. He believes that the Russian people are the most stateless people in the world, who, nevertheless, paradoxically managed to create one of the most powerful states in the world. At the beginning of the twentieth century, Berdyaev made an appeal to "kill the beast of politics". In particular, he writes, "It is unjust to recognize politics as the center of life ... The way of struggle of political parties, divorced from the center of life, from the meaning of it ... is unjust ... To bring politics as such to the very minimum, until the end of politics, it's in culture and religion, that's what should be our regulator ... here is the true liberation. Political liberation is a liberation from politics. We need to oppose to the statehood, violence of the authorities with a different beginning, a non-state, other, non-violent public" [5]. If this statement is interpreted ideologically, then this is liberalism, brought to anarchism, reducing the state to a minimum, up to the denial of the state. If we consider it ethically, then this is a denial of politics from the position of morality. 
It's no secret that most of the moral systems contain anti-political elements. Moral values are absolute, political ones, as mentioned above, are relative. And political thinking cannot do anything with absolutes: neither bypass, nor challenge, nor change. It can ignore them for a while, which often does, but politics, being detached from morals, is devoid of beliefs, and therefore turns out to be a niche of nihilism.

Contemporary politics is very clearly subject to money, not only in terms of venality, but in the sense that it is an employment activity, a "hire," a form of parasitic mediation. In fact, politics is the same as on the exchange, and rational schemes for making political decisions only cover and justify the clashes of groups exchanging goods and services. Politics is a kind of private profitable enterprise. The world is developing in the interests of economics and not in accordance with politics; political programs are insignificant, parliaments do not represent the will of the people but are controlled by the elites. Parliamentarism is only a facade, its decisions are an empty formality, and political parties are simple tools of oligarchic groups defending their own interests [1].

We have to state that the dehumanization of politics is taking place in the modern world. Political actions are not free actions. These are only useful and expedient for certain subjects of action, being devoid of moral significance and moral choice. Pragmatism, or rather, submission to either necessity or benefit, becomes the essence of politics.

It is not surprising, therefore, that politics is perceived by mass consciousness as a sad necessity and an inevitable evil, insignificant and transient in human life. There is a persistent conviction that simple and human decisions lie outside politics. Politics, in essence, is lifeless, only prevents to live.

We will especially mention the reason for the need to return morality to contemporary politics, which is singled out by E. Dubko. She writes that the mistress of politics must bear responsibility before morality, that is, take into account public opinion, but not at all because people have become more moral or caring about morality, but because politics is dentified with the activity for hiring; therefore, the engaged staff must report to the employer [1].

Agreeing with this conclusion, we add that, on the other hand, the identification of politics with wage activities, just like any other profession that generates earnings, has led to a catastrophic growth of amoralism in politics, which, moreover, is now often not considered necessary to hide. The catalyst for this process was the democratization, rationalization, and desacralization of political activity. And the active participation of church leaders in the development of the concept of political ethics, which was mentioned above, is really connected with the decrease of religiosity in the consciousness of contemporary society, which is one of the reasons for "getting rid" of politics from moral values. And in general, during the post-modern period, it is difficult to talk about any sustainable values in any sphere of human activity.

\section{Conclusion}

Thus, it would seem that citizens have the right to demand reporting from politicians, applying moral criteria to their activities in a democratic society.

But all this, unfortunately, does not mean that contemporary politics has become more humane and morally justified. On the contrary, we observe the reverse process. And, in our opinion, the efforts aimed at developing and affirming in the public consciousness political ethics, undertaken by Western authors since the revolutionary era of the late 1960s, including the Russian ones mainly in the last two decades, are dictated by the desire to at least somehow restore the broken links between politics and morality. Among other things, the introduction of moral guidelines into politics is a matter of continuing the existence and prospects for the development of mankind. 


\section{References}

1. E. L. Dubko, Political ethics (Academicheskiy Proyekt \& Triksta, Moscow, 2005)

2. H. Ortega y Gasset, Philosophskiye Nauki, 5 (1991)

3. H. Ortega y Gasset, The rebellion of masses: selected works (Worldwide, Infra-M, 2000)

4. A. A. Guseinov, Philosophy, morality, politics (Akademkniga, Moscow, 2002)

5. N. A. Berdyaev, Sub specie aeternitatis (Izdaniye Pirozhko, Saint Petersburg, 1907) 